\title{
Use of Remote Sensing and GIS in Monitoring Water Quality
}

\author{
Norsaliza Usali \& Mohd Hasmadi Ismail (Corresponding author) \\ Forest Surveying and Engineering Laboratory, Faculty of Forestry, Universiti Putra Malaysia \\ 43400 UPM, Serdang, Selangor, MALAYSIA \\ Tel: 60-3-8946-7220Ｅ-mail: mhasmadi@putra.edu.my
}

\begin{abstract}
The use of remote sensing and GIS in water monitoring and management has been long recognized. This paper however discusses the application of remote sensing and GIS specifically in monitoring water quality parameter such as suspended matter, phytoplankton, turbidity, and dissolved organic matter. In fact the capability of this technology offers great tools of how the water quality monitoring and managing can be operationalised in this country. Potential application and management is identified in promoting concept of sustainable water resource management. In conclusion remote sensing and GIS technologies coupled with computer modelling are useful tools in providing a solution for future water resources planning and management to government especially in formulating policy related to water quality.
\end{abstract}

Keywords: Remote sensing-GIS, Water quality parameter, Monitoring status, Sustainable water management

\section{Introduction}

Water is valuable natural resources that essential to human survive and the ecosystems health. Water are comprises of coastal water bodies and fresh water bodies (lakes, river and groundwater). Since the past few decades, the increasing of anthropogenic activities especially in industrial area has effects to water bodies. This is the global issues which happening throughout the world and Malaysia also face these problems. Today, with the advancement of science and technology, the population, industries, agriculture activities, and urban developments have grown up along the corridor or riverbanks of Malaysia. The domestic's sewage, factories effluents, and agriculture waste can lead to deterioration of river water quality. Because of that the river water quality monitoring program are needed in order to raise awareness of public by address the consequences of present and future threats of contamination to water resources. The characteristic of water can be categorized into three namely physical, biological and chemical. These characteristics are used in water monitoring program. In Malaysia, water quality monitoring program was done by the Department of Environment Malaysia (DOE). Report showed that in 2006, a total of 1064 monitoring station within 143 river basins were recorded. Out of these $638(60 \%)$ were categorized as clean, $376(35 \%)$ slightly polluted and $50(5 \%)$ were polluted respectively. The valuable data can be obtained to provide a basis comparison of state's stream at different seasons and different years. The monitoring and assessment may be useful for research and policy making purposes. In situ measurements and collection of water samples for subsequent laboratory analyses are currently used to evaluate water quality. These measurements are accurate for a point in time and space but do not give either the spatial or temporal view of water quality in wide space. Thus, the technologies such as remote sensing and GIS are very useful as a tool in evaluating and monitoring water quality.

\section{Water Quality Status in Malaysia}

In Malaysia, there were two main causes of river pollutants identified, namely land development for industry and natural-resources activity involving opening new agricultural area, and logging. These activities allow soil erosion to the water, increase matter mixture, turbidity, organic matter and river sedimentation problem. The latest data of river water and ground water quality was monitored by the Department of Environment Malaysia (DOE) in 2007. The monitoring program was started since 1978. A total of six water quality parameter were evaluate consists of Dissolved Oxygen (DO), Biochemical Oxygen Demand (BOD), Chemical Oxygen Demand (COD), Ammoniac Nitrogen (NH3-N), Suspended Solids (SS) and pH.

In Peninsular Malaysia, Sabah and Sarawak a total of 1,064 water quality monitoring stations is located within 143 river basins (Figure 1 and 2). Out of these, $638(60 \%)$ are categorized as clean, $376(35 \%)$ slightly polluted and $50(5 \%)$ polluted. Station located upstream were generally clean, while downstream were either slightly polluted or polluted. The major pollutants were Biochemical Oxygen (BOD), Ammonia Nitrogen $\left(\mathrm{NH}_{3}-\mathrm{N}\right)$ and Suspended Solids (SS). In Peninsular Malaysia (Figure 1), the polluted river (red color) mostly located at development and industrial area such as Sungai Pinang, Sungai Juru, Sungai Merlimau, Sungai Danga, Sungai Segget, Kawasan Pasir Gudang, and Sungai Tebrau. This was the serious matter that the government, policy maker, and public must be concern and take the conservation action to improve the river water quality for future generation and to mitigate river water quality from become worst.

\section{Monitoring Water Quality in Malaysia}

In Malaysia, there are a numbers of government departments and agencies that responsible for a particular component or function related to water resources but there is no single agency entrusted with the overall responsibility of holistic planning and management. For example, the Department of Irrigation and Drainage (DID) is responsible for the hydrology, river management, flood mitigation coastal management and storm water 
management. Besides, the Public Works Department responsible for domestic and industrial water supply and Department of Environment is for water pollution control. Conflicts in water resources management such as allocation of water rights, flood management, pollution control and environmental preservation are resolved through inter-agency coordination and consultation. The primary role of water resources management is expected to come from the state governments and their agencies since ownership and administration of water is a state matter under the Federal Constitution. Today, the National Water Services Commission or SPAN (Suruhanjaya Perkhidmatan Air Negara) is established where Act 2006 is used by the National Water Services Commission to supervise and regulate water supply services and sewerage services, and to enforce water supply and sewerage services laws and related matters. SPAN Act 2006 was begun to enforce in $1^{\text {st }}$ February 2007. Meanwhile, the National Hydraulic Research Institute of Malaysia (NAHRIM) was established in September 1995 under Ministry of Agriculture and then was placed under Ministry of Natural Resources and Environment. This organization was function to conduct both basic and applied research on water resources such as river, coastal, geo-hydrology, and water quality. Other than that, they also provide support services to public and private sectors as advisor in water and environmental problems.

Water quality index (WQI) and monitoring can be done by in situ measurement and any techniques. Remote sensing and GIS provides effective tools in monitoring of water quality parameter aid with in situ measurement data. The purposes of monitoring water quality parameter program are listed below:

(i) To rehabilitate and to improve the river water quality to achieve a clean condition.

(ii) To restore the water quality from Class III (WQI 51.68 to 75.37 , need the incentive water treatment for supply and suitable for aquatic life) to at least Class II (WQI 75.37 to 91.76, need water treatment for water supply and suitable for recreation)

(iii) To conserve, maintain and sustain the achieved improvement well after the project completion with the water quality status of at least Class II.

(iv) To promote and build smart partnership between public and private sector in projects related to pollution prevention, river rehabilitation and restoration works.

\section{Application of Remote Sensing in Monitoring Water Quality}

Water quality is the process to determine the chemical, physical and biological characteristics of water bodies and identifying the source of any possible pollution or contamination which might cause degradation of the water quality. These water quality indicators can be categorized as: (i) Biological: bacteria, algae, (ii) Physical: temperature, turbidity and clarity, color, salinity, suspended solids, dissolved solids, (iii) Chemical: $\mathrm{pH}$, dissolved oxygen, biological oxygen demand, nutrients (including nitrogen and phosphorus), organic and inorganic compounds (including toxicants) and (iv) Aesthetic: odors, taints, color, and floating matter.

Various studies have been reported on the usefulness of remote sensing as tools in monitoring of water quality (Ritchie and Charles, 1996; Dekker et al., 2002 and Schalles et al., 1998). Remote Sensing can be defined as a science and art of obtaining information about an object, area, or phenomena through the analysis of data acquired by device that is not in contact with the object, area, or phenomena under investigation (Thomas et al., 2004). Remote sensing of monitoring water quality has been started in the early 1970's. Ritchie et al., (1974) were developed an early empirical approach to estimates suspended sediments general equation as follows:

$$
\mathrm{Y}=\mathrm{A}+\mathrm{BX} \text { or } \mathrm{Y}=\mathrm{AB}^{\mathrm{X}}
$$

where, $\mathrm{Y}$ is the remote sensing measurement (i.e., radiance, reflectance, energy) and $\mathrm{X}$ is the water quality parameter of interest (i.e., suspended sediment, turbidity). A and B are empirically derived factors that this value are gained from statistical relationship which determined from spectral reflectance value and between the in situ water quality parameter. From the spectral reflectance it can give the information about the band or wavelengths are suitable for that water quality parameter. This equation later on was applied by other researcher to estimates water quality parameter. In future, if the empirical equation was successful developed for each water quality parameter, the equation can be used to estimates the same water quality parameter on area under investigation.

\subsection{Suspended Matter}

Suspended matter comprises organic and inorganic matter. Suspended matter plays an important role in water quality management since it is related to total primary production and fluxes of heavy metals and micro-pollutants. Suspended matters are the most common pollutants in surface water. Some researcher has discussed the relationship between suspended sediment and reflectance. The suspended sediments increases the radiance from surface water in visible and near infrared ranged of the electromagnetic spectrum (Ritchie and Charles, 1996). In situ and laboratory measurement has shown that the surface water radiance is affected by sediments type, texture, color, sensor view and sun angles, and water depth (Ritchie and Frank, 1998).

Remote sensing techniques can be used to estimate and map the concentrations of suspended matter in inland water, providing both spatial and temporal information. Remote sensing studies of suspended matter have been using from various of satellite platform such as Landsat, SPOT, IRS, Coastal Zone Color Scanner (CZCS) and Sea- viewing Wide Field of View Sensor (SeaWiFS). Those studies have shown a significance relationship 
between suspended matter and radiance or reflectance from either single band or combination of some bands in satellite or airborne platforms. By in situ studies, the wavelength between 700 and $800 \mathrm{~nm}$ were the most useful range for determining suspended matter in surface water (Ritchie et al., 1976). The absorption of radiance by suspended sediment is generally much smaller than that of chlorophyll, but the scattering is much higher. In term of optical wavelength, remote sensing of terrestrial is wide compare to the remote sensing of water bodies which is restricted to relatively narrow range. Therefore, the range of 400 to $850 \mathrm{~nm}$ is specific used at estimation of water quality parameter. Several investigators have found that TM4 (Landsat image) has a good relationship with TSM, and would be suitable for estimating suspended matter (Dekker et al., 2002).

\subsection{Phytoplankton}

Eutrophication of a water bodies can be quantified in term of concentration of chlorophyll contained in the algal plankton cells. Chlorophyll is one of the photosynthetic agents, contributing to the color of water. A large volume of literature exists on using remote sensing for mapping chlorophyll a, an indicator of algal concentration and a key parameter for assessment of water quality (Schalles et al., 1998). Although inland waters (e.g., lakes, rivers, reservoirs) usually have a higher range of Chlorophyll a and thus a stronger signal, the independent variations in Colored Dissolved Organic Matter and particulates have impeded the routine extraction of Chlorophyll a from ocean color measurements inshore.

Knowledge about the amount of phytoplankton has important implications for primary production and carbon cycle models as well as for monitoring the state of water bodies. A large uncertainty in detection of the amount of chlorophyll occurs during cyanobacterial blooms. Some success in the quantitative mapping of cyanobacteria has been achieved using airborne remote sensing (Dekker, 1993). For example, broadband sensors like AVHRR Ha'kanson and Moberg (1994), multispectral sensors such as CZCS and SeaWiFS (Siegel and Gerth, 2000), and synthetic aperture radars (Svejkovsky and Shandley 2001) have been used to map the extent of cyanobacterial blooms. Remote sensing has also been used to measure chlorophyll concentration and patterns. Most remote sensing studies of chlorophyll in water are based on empirical relationship between radiance in narrow bands or bands ratio and chlorophyll concentration. Measurement from aircraft, Landsat, SPOT, SeaWiFS and CZCS has used a variety algorithms and wavelength to map chlorophyll of the oceans, estuaries and fresh water. In principle, chlorophyll absorption occurs in short wavelengths. Hyperspectral sensors have been considered as the future sensors to measure chlorophyll concentration in water. The reflectance height at $690 \mathrm{~nm}$ above the base line from $670 \mathrm{~nm}$ to $850 \mathrm{~nm}$ was a sensitive indicator for chlorophyll concentration (Gitelson et al., 1995). Figure 3 shows a Chlorophyll $a$ map of Pensacola Bay Estuary, Florida derived from Landsat 7 ETM+ (Luoheng and Karen, 2005). Techniques used were band rationing and regression where the ratios of ETM $+1 / \mathrm{ETM}+3$ were found the most effective in estimating chlorophyll $a$.

\subsection{Turbidity}

Water turbidity is an expression of the optical properties of water, which cause the light to be scattered and absorbed rather than transmitted in straight lines. It is therefore commonly regarded as the opposite of clarity. As water turbidity is mainly caused by the presence of suspended matter, turbidity measurement has often been used to calculate fluvial suspended sediment concentrations (Wass et al., 1997). The best correlation of turbidity of reflectance was red reflectance, which is consistent with the results of (Lathrop and Lillesand, 1986). Other satellite data such as IKONOS demonstrates the usability of high-resolution satellite data for mapping turbidity in the Lower Charles River, USA (Ferdi et al., 2007).The higher resolution satellite like IKONOS has a potential solution to the limitation of spatial scale. The map of the turbidity was produced as shown in Figure 4.

The study of turbidity was also conducted by Liza (2007) in ice marginal lake at the Bering Glacier, Alaska. Simple and multiple linear regression analyses were conducted using different Landsat 7 ETM-F bands to determine the best predictor(s) of turbidity in glacial lakes. The final algorithm utilized Landsat 7 ETM+ Band 3 (red portion of the electromagnetic spectrum) and Band 4 (near-infrared portion of the electromagnetic spectrum) data to predict turbidity concentrations. In this study, turbidity maps created using the algorithm can be used to help determine inter- and intra annual sediment dynamics of Vitus Lake. This information could be used to help researchers predict significant glacial events such as outburst floods or surge events. The turbidity maps could also provide insight into the hydrologic routing of the Bering Glacier system by showing where the Glacier is discharging sediment-laden freshwater into Vitus Lake through subsurface conduits. The turbidity algorithm also has broader applicability to other glacial lakes in south central Alaska and potentially glacial lakes worldwide. Other studies has been conducted in turbidity mapping were carried out by Brezonik (2005), where he found that Landsat 5 TM Band 3 was the best predictor of turbidity in several Minnesota Lakes, and (Wang et al., 2006) concluded that Landsat 5 TM Band 2, Band 3/Band 2, Band 4/Band 3, and a multivariate regression analysis using Bands 3 and 2 are best predicted turbidity in Reelfoot Lake, Tennessee.

\subsection{Dissolved Organic Matter}

Dissolved organic matter affecting the colour of water is called gilvin, it is also called colored dissolved organic matter, aquatic humus, Gelbstoff or yellow matter. Those terms refer to all soluble organic substances (that can pass a $0.45 \mu \mathrm{m}$ filter) that contribute significantly to the absorption of light at certain wavelength. Colored 
Dissolved Organic Matter (CDOM) consists of naturally occurring; water-soluble, biogenic, heterogeneous organic substances that are yellow to brown in color (Aiken et al., 1985). CDOM is the fraction of dissolved organic matter that absorbs light in both ultraviolet and visible range. Dissolved organic matter also affects the volume reflectance volume spectrum, but almost exclusively at the shorter wavelengths (Bukata et al., 1985). CDOM absorbs visible light especially below $\sim 500 \mu \mathrm{m}$, and its absorbance increases exponentially with decreasing wavelength. Nonetheless, (Strombeck, 2001) reported that absorbance of red light can be significant at high CDOM concentrations. From a beneficial standpoint, the strong absorption of CDOM in the UV portion of the spectrum protects phytoplankton and other biota from damaging UVB radiation (Green and Blough, 1995). However at increasing levels, CDOM absorption can affect primary productivity and ecosystem structure by reducing the amount and quality of photosynthetically active radiation to phytoplankton.

CDOM concentrations also increase in coastal waters due to the in situ creation of folic acids produced from the seaweed decomposition (Sieburth and Jensen 1969), as a by product of primary production stimulated by nutrients (Del Castillo et al., 1999) and the anthropogenic input of industrial or domestic effluents from populated area (Bricaud et al., 1981). In the coastal environment, the optical properties of CDOM change owing to seawater mixing and photo degradation.

\section{Remote Sensing-GIS in Monitoring Water Quality in Malaysia}

In Malaysia the application of remote sensing through water quality parameter monitoring is still new. Overall the purpose of the monitoring of water quality parameter in Malaysia using remote sensing technique are because of the limit of the field cost, to improve the information contents, to produce the digital map, and to monitoring the large scale monitoring of water quality that will offer the significance source of information. Some example of study done in Malaysia is at the Penang Island by MatJafri et al., (2001) using satellite scene from Malaysian Tiungsat-1 for water quality mapping around the island. The objectives of study were to determine the total suspended solid and to produce the water quality map. The best Tiungsat-1 image available for the study area did not have the coincident data of total suspended solid. To overcome this problem they correlated the Tiungsat- 1 image with the Landsat TM images that have the corresponding sea-truth data. From analysis, Landsat TM image of 20 January 2000 produced the highest correlation with the Tiungsat- 1 image. The data of in situ measurements shows positive correlations between DN and TSS with R and Root Mean Squared (RMS) values were 0.9256 and $3.6237 \mathrm{mg} / \mathrm{I}$ respectively. Such characteristics were also observed by other investigators using remote sensing data in the visible channel for suspended sediment studies (Choubey, 1998).

Figure 5 depicted higher concentrations of Total Suspended Solids were distributed near the river mouths and the shallow at the southern region of the channel. The plumes in the river mouths were created by river discharges. In the shallow water, the turbidity might be caused by bottom due to waves and wind actions. The concentration seems to be relatively lower in the deeper part of the sea. From the study, total suspended water quality map around Penang Island was successfully produced using Tiungsat- 1 image. However, they unable to establish the validity of the apparent higher concentration on the west coast of Penang Island because of the absence of sea-truth data.

Other example is a prediction of groundwater potential zone in Langat Basin using integration of remote sensing and GIS (Khairul et al., 2000). Ground water cannot be detected directly from the earth's surface, so by remote sensing and GIS technique it can provide information concerning its potential occurrence. The purpose of study was to predict the groundwater potential zone through the various thematic maps from remote sensing and GIS technique. From results, almost all the Langat basin is an alluvial plains where have high potential of groundwater occurrence (Figure 6). The map is comprised of five categories of groundwater yield; very high, high, moderate, low and very low. The DRASTIC model in GIS was developed to produce a ground water potential zone using one climatic and seven biophysical parameters. In a steep mountainous area underlain by granite with low lineament density, the potential for groundwater is very low. Meanwhile in hard rock areas, the groundwater potential is high in areas with high lineament density and low drainage density. Satellite data has been proven to be very informative and useful in detecting a surface features and characteristics such as lineaments and land use.

Integrated assessment of thematic maps using model based on GIS techniques is the most suitable method for groundwater potential prediction zoning. However, this study was effective only for groundwater zone prediction in hard rock terrain, but was less effective in the alluvium environment. Monitoring and mapping water quality by remote sensing were also has been done in Langat and Semenyih Dam in 2000 using Landsat TM data (Mohd Hasmadi and Kamaruzaman, 1999; Mohd Hasmadi and Kamaruzaman, 2000). Langat and Semenyih dams are importance source of water supply to almost 1.9 million people in surrounding area and Kuala Lumpur City. From the regression model between in situ data and spectral reflectance from the satellite imagery, the Band TM3 and TM4 was the best model used to estimate Turbidity and it found that the value of turbidity (Figure 7) in Semenyih dam (left) and Langat dam (right) were 5.0 NTU and 7.0 NTU, respectively. These values are still considered as low and safe for public purposes. However, some control actions should be planned to ensure the rate of sediment transportation would not affect the water quality in the dam in near future. Another researcher 
(Sultan et al., 2004) has used algorithm to determine the turbidity distribution on surface of seawater in Penang, Malaysia. The algorithm was developed on digital camera imagery based on the reflectance model for Total Suspended Solids (TSS). Various types of algorithms were tested and their accuracies were noted. Finally, the optimum algorithm was selected and used to generate a turbidity map (Figure 8).

\section{Advantages of Remote Sensing in Monitoring Water Quality}

One major advantage of remote sensing observations over traditional measurements for water quality monitoring provides both spatial and temporal information of surface water characteristics (Lindell et al., 1999). With present advanced satellite sensors, a large number of water quality information about chlorophyll-a, suspended sediment, yellow substance, turbidity, Secchi disk depth, wave height, color index and surface water temperature can be observed on a regular basis (Zhang et al., 2002). Besides, remote Sensing technique has been widely used for water quality studies in coastal and inland lakes (Koponen et al., 2002). Remotely sensed data have the potential to provide knowledge of broad scale changes, the link between offshore and near-shore waters, and the ability to obtain a long-term, near-daily view of the region of interest indicating seasonal and inter annual variability. Other than that, by advanced technology from remote sensing it is a cheaper and repetitive quantitative technique for measuring water quality that will allow adequate management. It was various previous literatures that indicate success in using remote sensing to assess water quality such as in (Baban, 1993).

Compare to limnological studies, in situ measurements is often restricted to selected sampling points. But by Remote sensing data it provides the synoptic view of the water body, obtain to measures the characteristics of an area rather than a point, can integrate several characteristics with one composites measurements and ability to improve models with continuous or frequent feedback from satellite measurements. An intensive in situ sampling programmed can validate the remotely sensed products as well as provide an assessment of factors not able to be observed from space such as changing biota, substrate and chemical makeup. An improved understanding of these factors, and how they relate to remotely sensed products may enable development of remotely sensed environmental indicators, able to be monitored using space based measurements, but related to characteristics of the environment not directly observable from space.

\section{Conclusion}

Water provides variety purpose such as a source of water supply for domestic and industrial use, irrigated agriculture, livestock and mining activities. However by the increasing of the industrial development and anthropogenic activities the quality of water has decreased dramatically. Therefore, the monitoring programs using remote sensing and GIS are needed to threats all contamination occurs and provides the effective action at all levels. The remote sensing and GIS techniques are the effectiveness, cheaper and valuable tools in monitoring water quality parameter in coastal level and fresh water bodies (lakes, river, ground water, and reservoir) compared to in situ where measurement is restricted to selected sampling points. From the example of the past research by remote sensing and GIS techniques it was concluded that water quality parameter can be produced in the form of map using the algorithm or models by various platforms of satellite imagery with various resolutions such as Landsat, SPOT, IKONOS, IRS, CZCS, hyper spectral and SeaWiFS. Newly developed hyperspectral imaging, which can simultaneously record up to $200+$ spectral channels, is a much more powerful probe. Hyperspectral imaging has greater potential because of its simultaneous collection of images covering many narrow, contiguous wavelength bands that allow various aspects of water quality to be measured and monitored. Each water quality parameter such as suspended matter, phytoplankton concentration, turbidity, and dissolved organic matter has their own estimation reflectance within the range of $400-850 \mu \mathrm{m}$. In the future the solution to water quality issues can be solved rapidly using these technologies for sustainable water resources management.

\section{References}

Aiken, G. R., McKnight, D. M., R., Wershaw, L., and MacArthy. (1985). Humic substances in soil, sediment and water: Geochemistry, isolation and characterization. J. Wiley and Sons, New York.

Baban, S.M .J. (1993). Detecting water quality parameter in Norfolk Broads, U.K. using Landsat imagery, Int. J.

Remote Sensing, 14, 1247-1267.

Brezonik, P., Kevin D. M., and Marvin, B. (2005). Landsat-based remote sensing of lake water quality characteristics, including chlorophyll and colored dissolved organic matter (CDOM). Lake and Reservoir Management, 21(4), 373-382.

Bricaud, A., Morel, A., and Prieur, L. (1981). Absorption by dissolved organic matter of the sea (yellow substance) in the UV and visible domains. Limnology and Oceanograph, 1, 43-53.

Bukata, R.P., J.H. Jerome, K.Y. Kondratyev, and Pozdnyakov, D.V. (1995). Optical properties and remote sensing of inland and coastal waters, CRC Press, Boca Raton, Florida, $362 \mathrm{p}$.

Choubey, V. K. (1998). Laboratory experiment, field and remotely sensed data analysis for the assessment of suspended solids concentration and secchi depth of the reservoir surface water. Int. J. of Remote Sensing, 19, 3349-3360. 
D.O.E. (2007). Malaysia Environmental Report Quality, (2007). Department of Environment Ministry of Natural Resources and Environment Malaysia. Petaling Jaya, Malaysia. 84pp.

Dekker, A. G. (1993) Detection of optical water quality parameters for eutrophic waters by high resolution remote sensing. Vrije Univ, Amsterdem, the Netherlands, Ph.D. thesis. $222 \mathrm{p}$.

Dekker, A.G., Vos, R.J., and Peters, S.W.M. (2002) Analytical algorithms for lake water TSM estimation for retrospective analyses of TM and SPOT sensor data. Int. J. of Remote Sensing. 23, 15-35.

Del Castillo, C., Coble, P., MorelI, J. M., Lopez, J. M. and Corredor, J. E. (1999). Analysis of the optical properties of the Orinoco River plume by absorption and fluorescence spectroscopy. Marine Chemistry, 66, 35-51.

Ferdi, L.; Miller, Will,O. and Kehinde,S. (2007). Mapping turbidity in Charles River, Boston using a high resolution satellite. Environmental Monitoring and Assessment, 132(1-3), 311-320

Gitelson, A., Yacobi, Y., Karniell, A., and Kress, N. (1995). Remote estimation of chlorophyll concentration in polluted marine waters in Haifa Bay, Southeastern Mediterranean. Proceedings of SPIE.pp: 44-54.

Green, S. \& Blough, N. (1995). Optical absorption and fluorescence properties of chomophoric dissolved organic matter in natural waters. Limnology and Oceanography, 39 (8), 1903-1916.

Ha'kanson, B. G., and Moberg, M. (1994). The algal bloom in the Baltic during July and August 1991, as observed from NOAA weather satellites. Int. J. Remote Sensing, 15, 963-965.

Khairul, A.M., Juhari, M.A., and Ibrahim, A. (2000). Groundwater prediction potential zone in Langat Basin using the integration of remote sensing and GIS.GISdevelopment. [Online] Available: http://www.gisdevelopment.net/aars/acrs/200 (Mac 7, 2010).

Koponen, S., Pulliainen, J., Kallio, K., and Halliainen, M. (2002). Lake water quality classification with airborne hyperspectral spectrometer and simulated MERIS data. Remote Sensing of Environment, 79,51-59.

Lathrop, R. G., Jr., and Lillesand, T. M. (1986). Use of thematic mapper data to assess water quality in Green Bay and central Lake Michigan, Photogrammetric Engineering and Remote Sensing, 52(5), 671-680.

Lindell, T., Pierson, D., Premazzi, G., and Zilioli, F. (1999). Manual for monitoring European lakes using remote sensing techniques, (EUR 18665 EN, Official Publications of the European Communities, Luxembourg. $161 \mathrm{p}$.

Liza K. L. (2007) Turbidity mapping and prediction in ice marginal lakes at the bering glacier system, Alaska. M.Sc Thesis, University of Michigan.50p.

Louheng,H. and Karen, J.J. (2005). Estimating and mapping chlorophyll-a concentration in Pensacola Bay,Florida using Landsat ETM+ data. International Journal of Remote Sensing, 26(23),5245-5254.

MatJafri, M.Z., Abdullah, K., and Lim, H.S. (2001). Malaysia Tiungsat-1 imagery for water qualitymapping.GlSdevelopment.[Online] Available: http://www.gisdevelopment.net/applicationlnrml (Mac 5, 2010).

Mohd. Hasmadi Ismail and Kamaruzaman Jusoff. (2000). Water turbidity mapping in Semenyih dam using remote sensing technique. Proceeding of Malaysian Science \& Technology Congress 2000: Research \& Development in Science \& Technology for the New Era, 18-20 September 2000, Promenade Hotel, Kota Kinabalu, Sabah.pp: 191-198.

Mohd. Hasmadi Ismail and Kamaruzaman Jusoff. (1999). Preliminary mapping of water turbidity in Langat and Semenyih dam using satellite remote sensing data. Paper Presented at Malaysian Science \& Technology Congress 1999,8-10 November 1999, Hilton Hotel, Kuching, Sarawak, Malaysia.

Ritchie, J.C and Schiebe, F.R. (2000). Water quality. In: G.A. Schultz and E.T. Engman (eds.), Remote sensing in hydrology and water management, Springer-Verlag, Berlin: Germany, 287-303; 351-352

Ritchie, J.C., and Charles, M.C. (1996). Comparison of Measured Suspended Sediment Concentration Estimated from Landsat MSS data. Int J. Remote Sensing, 9(3), 379-387.

Ritchie, J.C., Schiebe, F.R and McHenry, J.R. (1976). Remote Sensing of Suspended Sediment in Surface Water. Photographic Engineering Remote Sensing, 42, 1539- 1545.

Schalles, J. F., Gitelson, A. A., Yacobi, Y. Z., and Kroenke, A. E. (1998). Estimation of chlorophyll a from time series mesurements of high spectral resolution reflectance in an eutrophic lake. J. of Physiology. 34, 383-390.

Sieburth, J., and Jensen, A. (1969). Studies on algal substances in the sea. II. The formation of gelbstoff (humic material) by exudates of phaeophyta. J. of Experimental Marine Biology and Ecology, 3, 275-289.

Siegel, H., and Gerth, M. (2000). Remote-sensing studies of the exceptional summer of 1997 in the Baltic Sea: The warmest August of the century, the Oder flood, and phytoplankton blooms In D. Halpern (eds.), Satellites, oceanography and society. Elsevier Science. 239-255p. 
Strombeck, N., and Pierson, D.C. (2001). The effects of variability in the inherent optical properties on estimations of chlorophyll a by remote sensing in Swedish freshwaters. Sci. Tot. Environments. 268,123-137.

Sultan, A., Lim, U.S., MatJafri, M.Z., Abdullah, K., and Bakara, M.N.A. (2004). Remote sensing of turbidity mapping from digital camera imagery. GlSdevelopment. [Online] Available: http://www.gisdevelopmentnetlaars/acrs/2004J (Mac 7, 2010)

Svejkovsky, J., and Shandley, J. (2001). Detection of offshore plankton blooms with AVHRR and SAR imagery. Int. J. Remote Sensing. 22, 471-485.

Thomas, M.L., Ralph, W.K. \& Jonathan, W.C., ed. (2004). Remote Sensing and Image Interpretation, $5^{\text {th }}$ ed. United States of America. 461pp.

Wang, F., Han, L., Kung, H.T., and Van Arsdale, R. B. (2006). Applications of Landsat5 TM imagery in assessing and mapping water quality in Reelfoot Lalce, Tennessee. Int. J. of Remote Sensing, 27(23), 5269-5283.

Wass, I. D., Marks, S. D., Finch, J. W., Leeks, G. J. L. hd Ingram, J. K. (1997). Monitoring and preliminary interpretation of in-river turbidity and remote sensed imagery for suspended sediment transport studies in the Humber catchment, The Science of The Total Environment, 194-195, 263- 283.

Zhang, Y., Pulliainen, J., Koponen, S., and Hallikainen, M. (2002). Application of an empirical neural network to surface water quality estimation in the Gulf of Finland using combined optical data and microwave data. Remote Sensing of Environment, 81(2-3), 327-336.

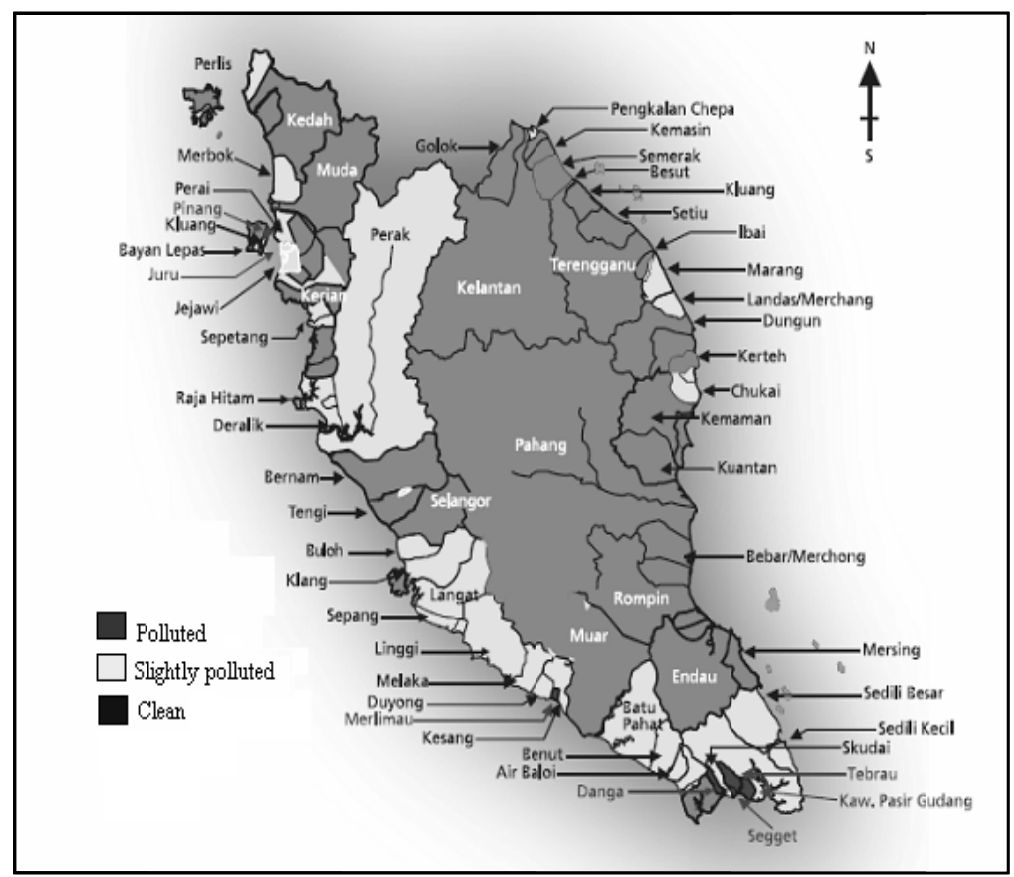

Source: DOE, 2007

Figure 1. Water quality status of river basins in Peninsular Malaysia, 2007. 


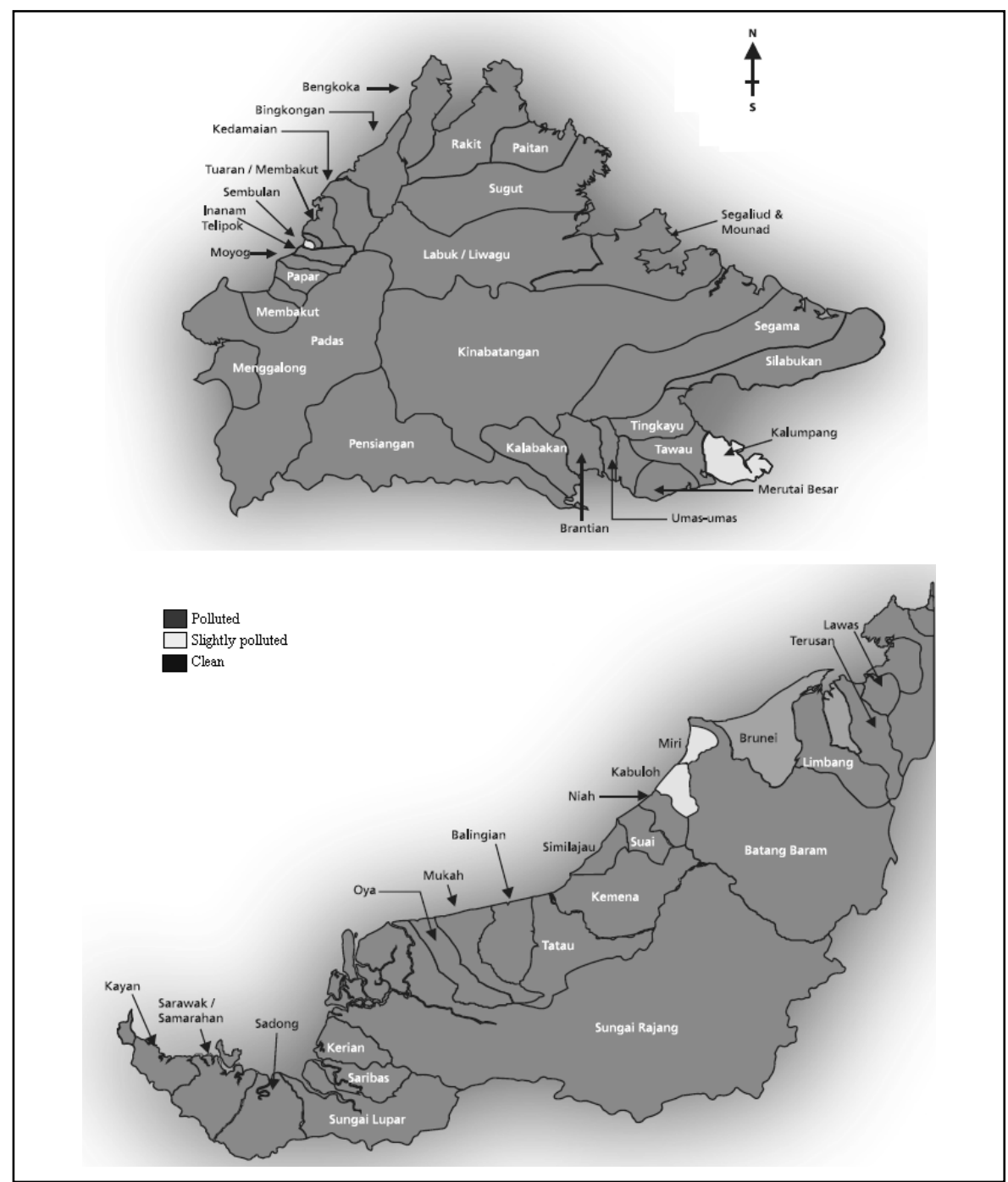

Source: DOE, 2007

Figure 2. Water quality status of river basins in Sabah (top) and Sarawak (bottom), 2007.

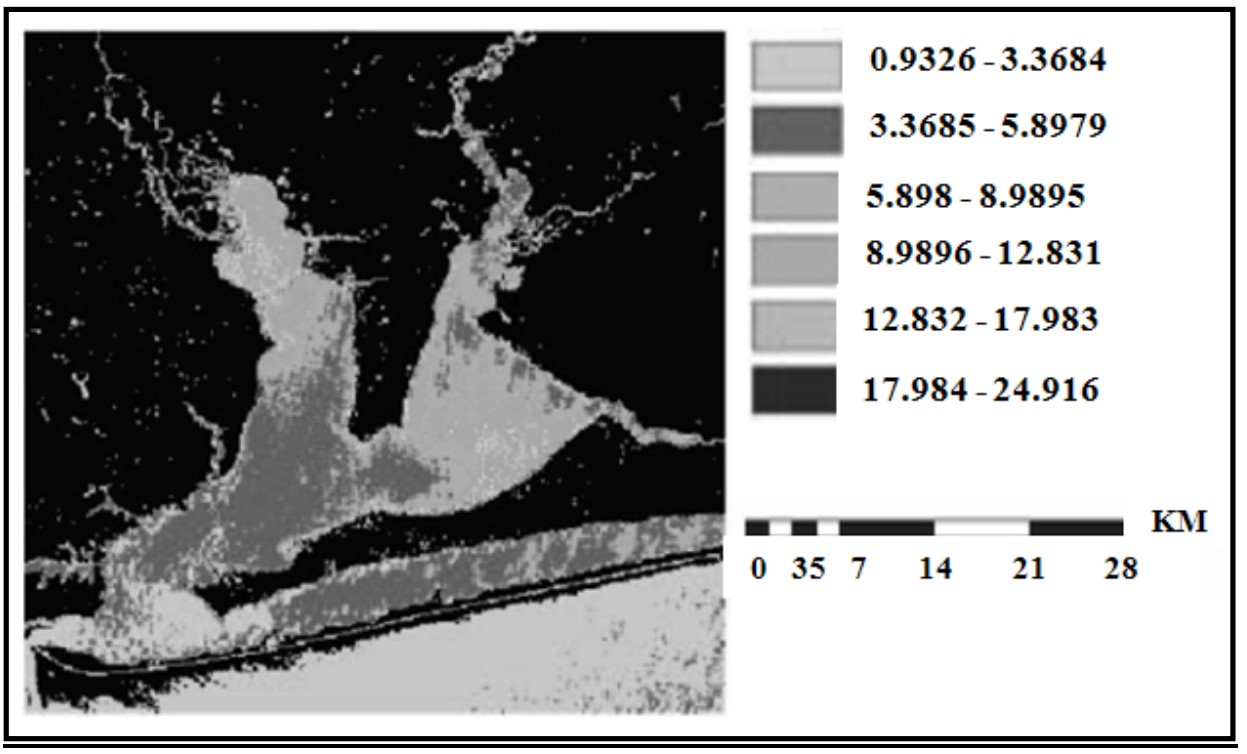

Figure 3. Chlorophyll $a$ map of Pensacola Bay, Florida,USA. 




Figure 4. Map of turbidity in the Lower Charles River in Boston,USA.

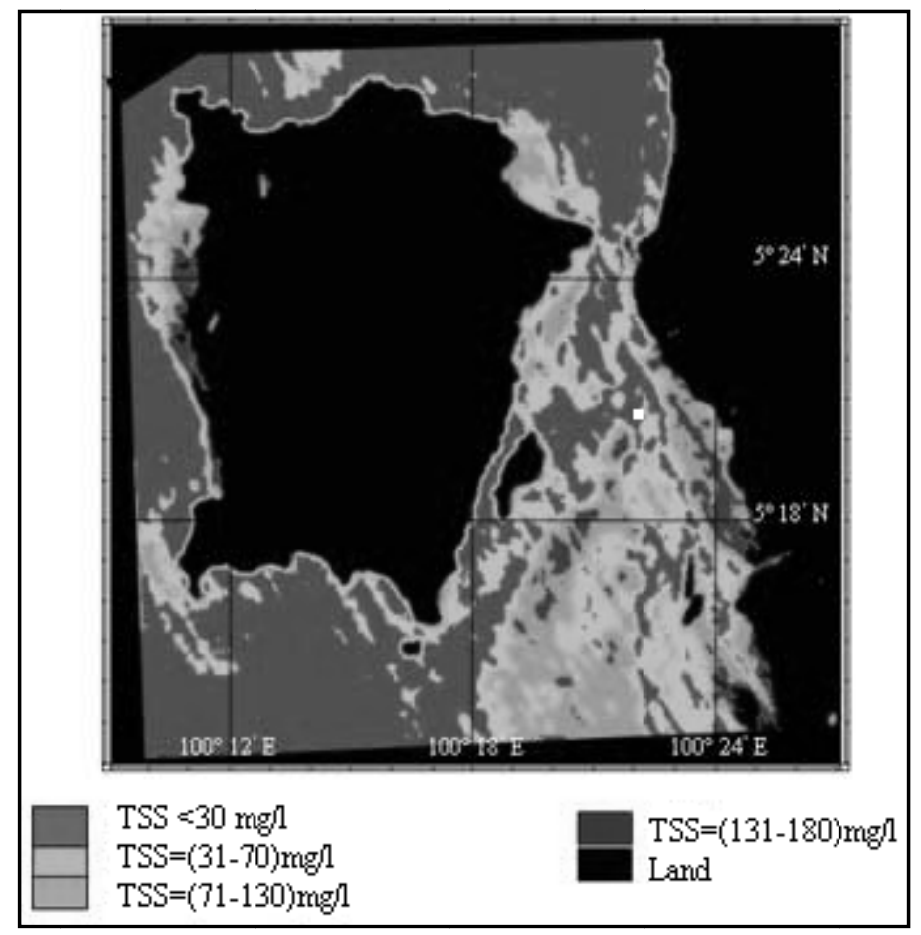

Figure 5. Total Suspended Solids (TSS) map of Penang Island, Malaysia 


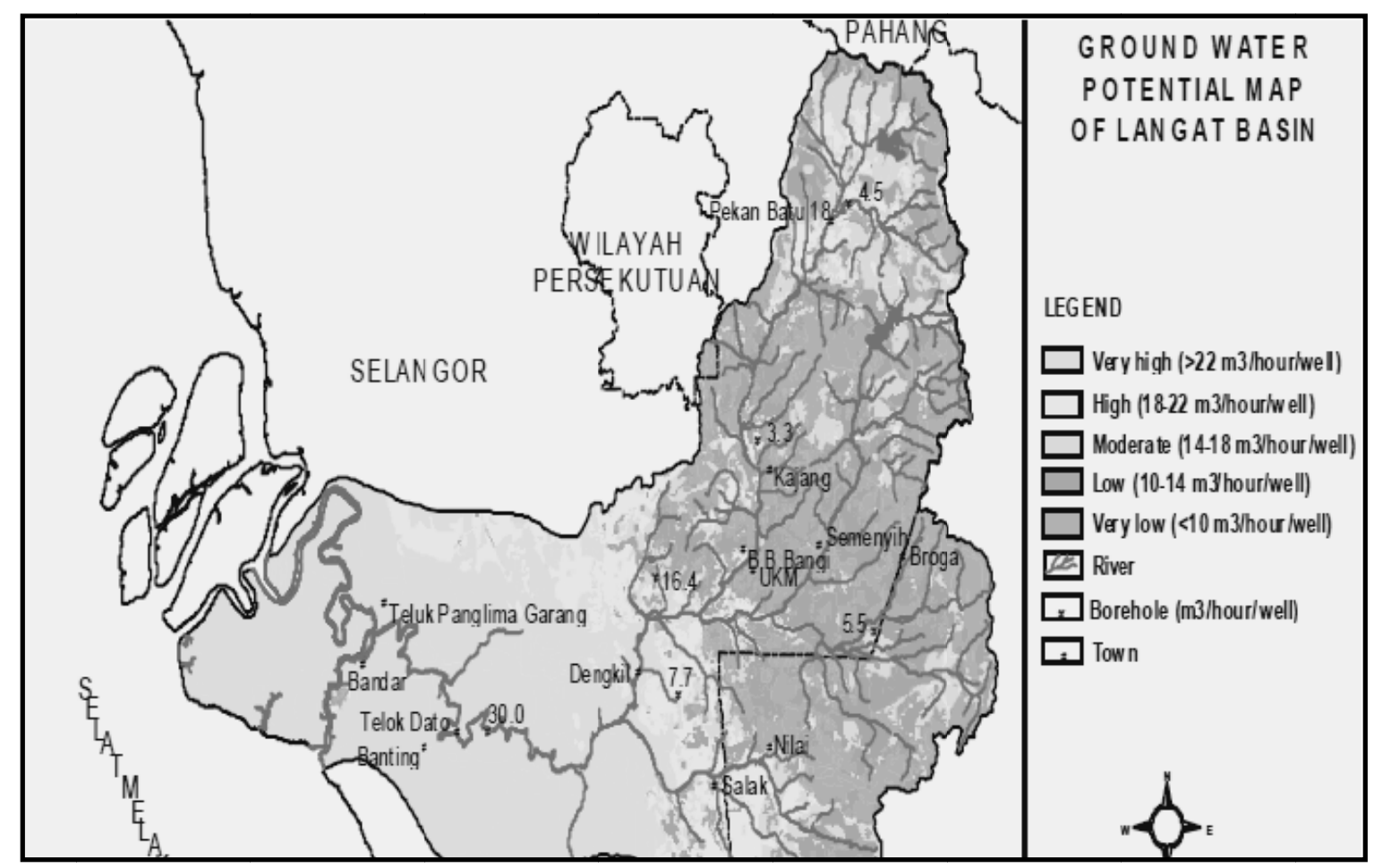

Figure 6. Groundwater potential map of the Langat Basin, Malaysia

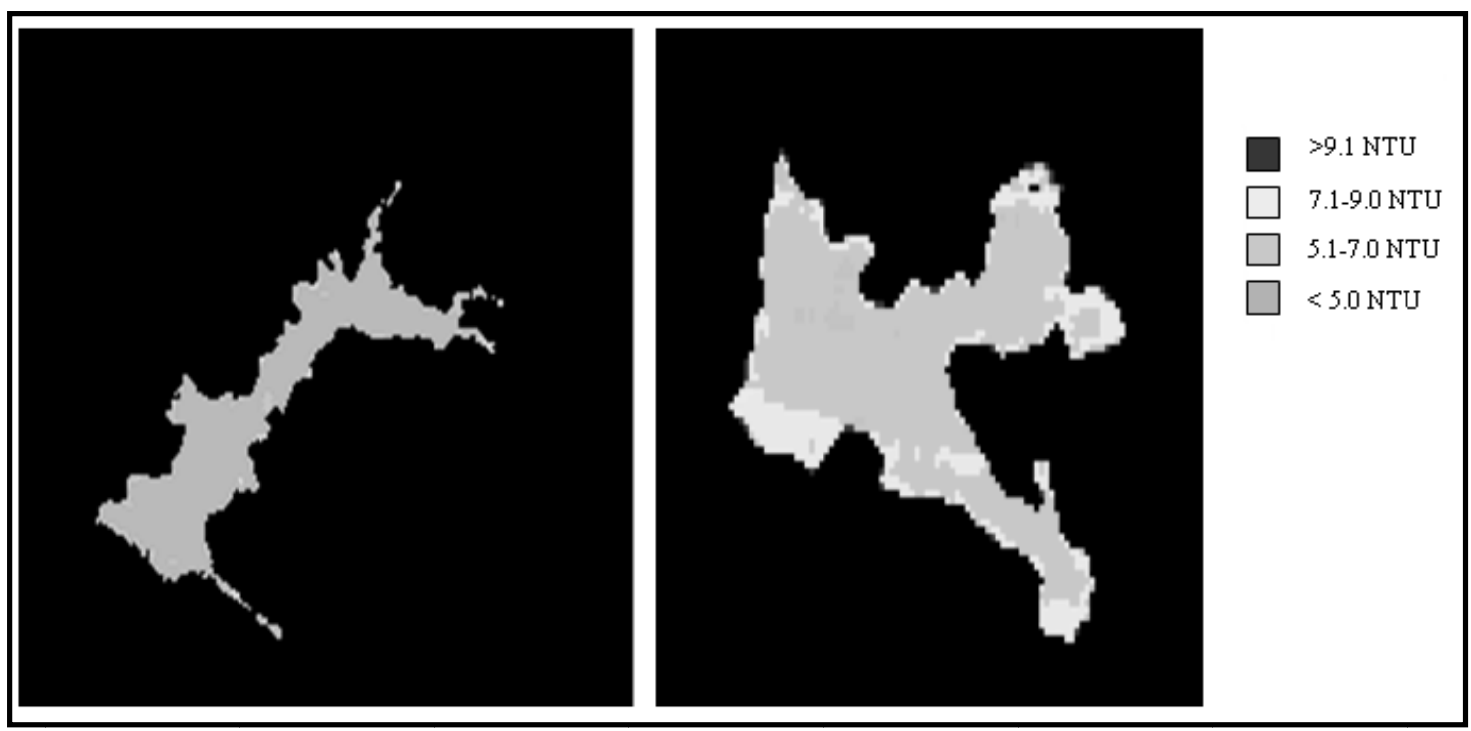

Figure 7. A maps of turbidity level of Semenyih (left) and Langat dam (right) 


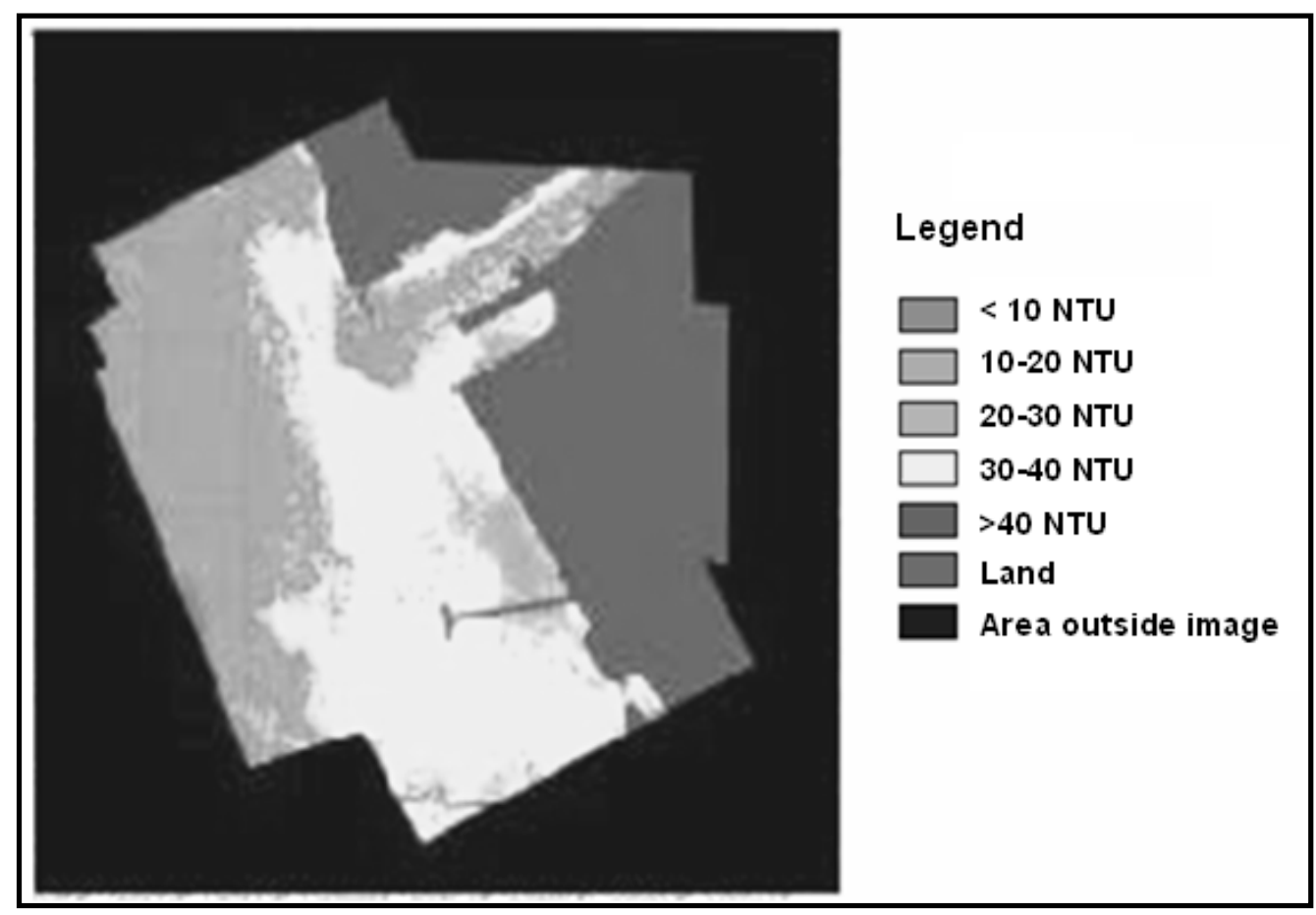

Figure 8. A map of turbidity near Prai River estuary, Penang 